\title{
BAUMGARTEN (Jean), BUNIS (David), éds., Le Yiddish. Langue, culture, société
}

Paris, C.N.R.S Éditions, Centre de recherche français de Jérusalem, 1999, $282 \mathrm{p}$.

\section{Régine Azria}

\section{OpenEdition}

\section{Journals}

Édition électronique

URL : http://journals.openedition.org/assr/20846

DOI : $10.4000 /$ assr. 20846

ISSN : $1777-5825$

Éditeur

Éditions de l'EHESS

\section{Édition imprimée}

Date de publication : 1 juin 2001

Pagination : 126-127

ISBN : 2-222-96704-X

ISSN : 0335-5985

Référence électronique

Régine Azria, «BAUMGARTEN (Jean), BUNIS (David), éds., Le Yiddish. Langue, culture, société », Archives de sciences sociales des religions [En ligne], 114 | avril-juin 2001, document 114.53, mis en ligne le 19 août 2009, consulté le 21 septembre 2020. URL : http://journals.openedition.org/assr/ 20846 ; DOI : https://doi.org/10.4000/assr.20846

Ce document a été généré automatiquement le 21 septembre 2020

(c) Archives de sciences sociales des religions 


\section{BAUMGARTEN (Jean), BUNIS (David), éds., Le Yiddish. Langue, culture, société}

Paris, C.N.R.S Éditions, Centre de recherche français de Jérusalem, 1999, $282 \mathrm{p}$.

Régine Azria

\section{RÉFÉRENCE}

BAUMGARTEN (Jean), BUNIS (David), éds., Le Yiddish. Langue, culture, société, Paris,

C.N.R.S Éditions, Centre de recherche français de Jérusalem, 1999, 282 p.

1 Ce recueil d'études et d'essais introduits par J.B. entend montrer la diversité de la culture yiddish et le renouvellement des problématiques et des méthodes que ce domaine d'étude connaît depuis ces dernières années.

2 Un premier ensemble d'articles est consacré à la place de la littérature yiddish ancienne au sein de la culture ashkénaze traditionnelle. Souvent associé aux courants séculiers de la culture juive, le yiddish a cependant joué un rôle important dans la diffusion de la tradition religieuse, notamment parmi les couches populaires, par le biais de sermons oraux et écrits. Mais c'est le recueil connu sous le nom de Mayse-bukh (livre d'histoires), l'ouvrage de vulgarisation religieuse le plus populaire du monde ashkenaze, destiné aux femmes et aux ignorants (sachant malgré tout lire!), qui a le plus contribué à assurer la fonction didactique du yiddish. Une des questions ici posée est la suivante : quel type de représentations de la femme, cette littérature populaire at-elle contribué à véhiculer?

3 La vitalité et l'expansion du hassidisme ont provoqué de très vives réactions d'hostilité, au sein du monde orthodoxe lui-même (mitnag-dim), mais aussi au sein des milieux éclairés (maskilim). C'est à l'abondante littérature polémique née de cette opposition et produite par ce dernier courant, que s'intéresse l'article suivant. Grâce à la violente 
controverse qu'il a suscitée, le hassidisme aurait été, à son corps défendant, le facteur unificateur et stimulant de la littérature des Lumières. La contribution suivante s'intéresse à l'art et à la fonction des bad-hanim, ces poètes amuseurs et improvisateurs qui animent les mariages hassidiques dans le monde ashkenaze : elle les replace dans leur contexte socio-historique et religieux et s'interroge sur leur devenir dans les sociétés juives actuelles, en Israël, mais aussi à New York et à Anvers où, quoique menacée, cette tradition orale est encore perpétuée.

Ce recueil vise aussi à démentir le caractère insulaire ou autarcique de la langue et de la culture yiddish. Pour preuve, les phénomènes de transferts de la culture ashkenaze vers la littérature séfarade; l'étude de littérature sépharade enjudezmo (judéoespagnol) témoigne en effet de l'influence de la culture ashkenaze et du yiddish hors de sa sphère propre. Dans une perspective du même ordre, l'étude de Chone Shmeruk, spécialiste du yiddish récemment décédé et auquel ce recueil rend hommage, s'intéresse à la culture moderne trilingue, hébreu-yiddish-polonais, des juifs polonais de la période de l'entre-deux-guerres. La démarche pluridisciplinaire de cet auteur apporte une contribution exemplaire et originale à l'étude des sociétés multiculturelles et plurilingues et aux phénomènes socio-linguistiques induits par les relations entre minorités et États-nations modernes.

Enfin, et c'est le dernier volet thématique de ce recueil, les AA. yiddish n'ont pas manqué de participer aux nouveaux courants esthétiques et aux avant-gardes modernes. Les deux articles sur lesquels l'ouvrage se clôt en fournissent l'illustration, le premier avec l'étude de la revue littéraire Yung Yiddish, créée à Lodz en 1919, qui publie la jeune littérature et qui associe peintres et poètes; le second avec l'évocation de l'écrivain yiddish, Leyb Kvitko, dont l'engagement communiste ne l'empêche pas de produire, à côté de textes politiques, des récits de science-fiction et des récits d'espionnage. Malgré son attachement à la cause de la Révolution, il fait partie du groupe d'écrivains yiddish fusillés le 12 août 1952. 